\title{
TEORI PERTIMBANGAN SOSIAL
}

Oleh :

\author{
I Ketut Sudarsana \\ Institut Hindu Dharma Negeri Denpasar \\ Email : $\underline{\text { iketutsudarsana@ihdn.ac.id }}$
}

Menurut Prof. DR. Mar'at bahwa perubahan sikap ditentukan oleh faktor internal dan paktor ekternal.

\section{Faktor Internal.}

a. Persepsi Sosial.

Penerima stimulus (respipien) dalam menangkap berita mempersepsikan orang yang memberikan informasi, melalui informasi sensorik. Dalam kaitannya dengan keputusan sosial terdapat keputusan sebagai berikut, pertama, individu mempersepsikan orang yang memberikan informasi menurut pengalamannya sebagai apa. Proses ini tergantung dari orang yang menerimainformasi menilai orang yang memberikan informasi (komunikator) proses selanjutnya adalah peran dari orang yang menerima informasi dalam mengambil keputusan, jika ada kesesuaian maka sikap individu sebagai penerima informasi dapat dipengaruhi dan terjadilah perubahan sikap. b. Posisi Sosial.

Penerima informasi akan mempersepsikan komunikator sebagai obyek yang mempunyai arti. Hubungan antara komunikator dengan penerima informasi memiliki hubungan langsung dalam kaitannya posisi dengan masyarakat. Oleh karena itu posisi komunikator dapat mengubah sikap individu atau kelompok. Arti posisi ini dapat memiliki nilai keagamaan, pemerintah yang dapat diandalkan, kepandaian, kejujuran dan sebagainya. Posisi sosial yang dipersepsikan memiliki nilai tertentu seperti nilai moral dan hal ini akan dikaitkan dengan pengambilan keputusan bagi si penerima berita untuk mengubah sikap.

c. Proses Belajar Sosial.

Penerima stimulus banyak dipengaruhi oleh pengalaman dan kemampuan. Tiap berita atau informasi akan senantiasa diolah nilai, disaring demi kepentingannya, jika hal ini menguntungkan bagi penerima berita, maka individu ini senantisa menerima dan mengolahnya melalui pengalaman dan berarti terdapat proses belajar. 


\section{Faktor eksternal.}

a. Penguatan (reinforcement)

Untuk keberhasilan untuk mengubah sikap maka komunikator perlu memberikan tambahan stimulus (penguatan) agar penerima berita mau mengubah sikap. Hal ini dapat dilakukan dengan berbagai cara seperti dengan pemberian imbalan atau hukuman. Dengan cara demikian ini penerima berita / informsi akan mempersepsikan sebagai suatu arti yang bermanfaat bagi dirinya dan adanya sanksi bila hal ini tidak dilakukan maka dengan sendirinya penguatan ini harus dapat dimengerti dan diterima sebagai hal yang mempunyai efek langsung terhadap sikap.

b. Kominikasi persuasif.

Komunikasi persuasif merupakan kegiatan penyampaian suatu informasi atau masalah kepada orang lain dengan cara menbujuk (kegiatan ini adalah "influencing the emotional attitude of others" yang berarti mempengaruhi sikap emosi dari pihak lain. Ini biasanya dilakukan pada mereka yang rasionya cukup baikdan persepsi sosialnya selektif. Pendekatan dengan melalui komponen efeksi adalah dengan cara emosional adalah dengan cara ini diterima dan ada keyakinan dalam dirinya atas kebenaran ide ini maka secara sadar akan timbul perubahan sikap. c. Harapan yang diinginkan.

Untuk keberhasilan mengubah sikap, komunikator senantiasa memperhatikan harapan yang diinginkan oleh pihak lain. Dan memenuhi segala keinginannya dengan demikian orang yang menerima informasi akan terpengaruh dan dengan sendirinya seorang dapat berubah.

Perubahan sikap dalam kaitannya dengan sikap keagamaan yang menyimpang merujuk kepada teori pertimbangan sosial ini tampak menyangkut paktor status sosial seseorang dalam masyarakat penyimpangan sikap keagamaan yang dipengaruhi oleh status sosial ini cenderung dilatar belakang harapan untuk mengembalikan kedudukan didalam masyarakat. Misalnya seseorang dihormati dalam masyarakat kemudian mendapatkan saingan dari tokoh lain. Karena kalah dengan persaingan tersebut pandangan masyarakat beralih pada tokoh pendatang baru. Maka untuk mengembalikan status yang pernah diperoleh kemungkinan besar ia cenderung untuk melakukan suatu yang menyimpang guna menarik kembali perhatian masyarakat yaitu untuk mengisi kekosongan wibawa yang hilang. 
Dilain pihak kemungkian juga sikap keagamaan yang menyimpang ditampilkan seorang tokoh dalam masyarakat dalam bentuk positip. Atas dasar pertimbangan untuk kepentingan masyarakat banyak. Sikap keagamaan yang menyimpang seperti ini dalam sejarah keagamaan umumnya diakhiri dengan munculnya kelompok baru yang mampu mengubah tatanan tradisi keagamaan yang ada.

\section{Daftar Pustaka}

Sudarsana, I. K. (2017, October). Makna Filosofis Asessorpenilaian Beban Kinerja Akademik Dosen Pendidikan Agama Hindu Pada Perguruan Tinggi. In Prosiding Seminar Pendidikan Agama (pp. 129-133).

Sudarsana, I. K. (2017, October). PENGEMBANGAN PENDIDIKAN BERBASIS KEARIFAN LOKAL UNTUK MEWUJUDKAN TOLERANSI ANTAR UMAT BERAGAMA. In Prosiding Seminar Nasional Filsafat (pp. 216-223).

Sudarsana, I. K. (2017, October). PERANAN ORANG TUA DALAM PENANAMAN BUDI PEKERTI PADA ANAK. In PROSIDING SEMINAR NASIONAL ANAK USIA DINI (SEMADI) 2 (pp. 157-160).

Sudarsana, I. K. PERAN KELUARGA DALAM MEMBENTUK KARAKTER ANAK USIA DINI. STRATEGI PEMBELAJARAN ANAK USIA DINI UNTUK MEWUJUDKAN GENERASI BERKUALITAS.
Sudarsana, I. K. (2017). Optimalisasi Pemahaman Ajaran Tri Hita Karana Dalam Meningkatkan Karakter Siswa Sekolah Dasar (Perspektif Psikologi Pendidikan). Prosiding Senada 2, 250-256.

Sudarsana, I. K. (2017). Menumbuhkan Minat Belajar Bahasa Bali Pada Kalangan Remaja. Prosiding Sembada 2017.

Sugiharta, I. P. S. O., \& Sudarsana, I. K. (2017). Hypnotic Learning Characteristics On Sisya Brahmakunta Community In Denpasar. Vidyottama Sanatana: International Journal of Hindu Science and Religious Studies, 1(2), 132-145.

Wisarja, I. K., \& Sudarsana, I. K. (2017). Praksis Pendidikan Menurut Habermas (Rekonstruksi Teori Evolusi Sosial Melalui Proses Belajar Masyarakat). Indonesian Journal of Educational Research, 2(1), 1826.

Sudarsana, I. K. PERAN KELUARGA DALAM MEMBENTUK KARAKTER ANAK USIA DINI. STRATEGI PEMBELAJARAN ANAK USIA DINI UNTUK MEWUJUDKAN GENERASI BERKUALITAS.

Wisarja, I. K., \& Sudarsana, I. K. (2017). REFLEKSI KRITIS IDEOLOGI PENDIDIKAN KONSERVATISME DAN LIBRALISME MENUJU PARADIGMA BARU PENDIDIKAN. Journal of Education Research and Evaluation, 1(4), 283-291. 